\author{
St ud i P hiloso phi c a \\ Wrat i s l a vi e n s i a \\ vol. XIII, fasc. 3 (2018) \\ DOI: $10.19195 / 1895-8001.13 .3 .9$
}

\author{
MATEUSZ KOTOWSKI \\ ORCiD: 0000-0002-1782-6365 \\ Politechnika Wrocławska
}

\title{
Argumenty z autorytetu a krytyczne myślenie. W nawiązaniu do Logiki i argumentacji Andrzeja Kisielewicza
}

\author{
[...] antymaterii obawiam sie mniej aniżeli Internetu. \\ Stanisław Lem ${ }^{1}$
}

Istnieje długa tradycja uznawania argumentu z autorytetu jako błędu w rozumowaniu bądź, jak określił to niegdyś za Boecjuszem Tomasz z Akwinu, ,najsłabszego argumentu" ${ }^{\prime 2}$ W artykule tym będę argumentował, że odwoływanie się do opinii autorytetów stanowi dziś często nieunikniony element racjonalnej argumentacji. Jednocześnie z koniecznością polegania w wielu kwestiach na opinii autory-

${ }^{1}$ S. Lem, Ryzyko Internetu, [w:] idem, Bomba megabitowa, Kraków 1999, s. 7.

${ }^{2}$ Co prawda św. Tomasz nie rozważał dokładnie tego, co zostało później określone mianem argumentum ad verecundiam (który jeszcze później zaczęto określać mianem argumentu z autorytetu), lecz stawiał pytanie o możliwe rodzaje uzasadnienia w kontekście pytania o właściwość uzasadniania ,nauki świętej”. W tym kontekście pisał: „Przypuśćmy, że [nauka święta - M.K.] może uzasadniać; w takim razie albo będzie powoływać się na jakieś powagi, albo opierać o rozum; powołanie się jednak na jakieś powagi, jak się wydaje, uwłacza jej własnej powadze, gdyż według Boecjusza argument z powagi jest najsłabszy [locus ab auctoritate est infirmissimus - M.K.]". Święty Tomasz z Akwinu, Suma teol. 1. 1, 8 ad 2; tłum. za: Suma teologiczna, t. 1., O Bogu, t. 1, tłum. P. Bełch, Londyn 1975, s. 38.

Co się zaś tyczy argumentum ad verecundiam, teoretycy argumentacji wskazują często jako źródło jego pierwszego sformułowania fragment Rozważan dotyczacych rozumu ludzkiego J. Locke’a: „Gdy ludzie są wyniesieni do wysokich godności, to wszelkie uchybienie ich godności ze strony innych i stawianie ich autorytetu pod znakiem zapytania jest uważane za uchybienie i brak należnego szacunku. [...] Każdy, kto swe poglądy opiera na takich autorytetach, mniema, że ze względu na nie powinien być górą w sporze i gotów jest nazwać zuchwalcem tego, kto przeciw niemu wystąpi. Myślę, że można to nazwać argumentum ad verecundiam" (J. Locke, Rozważania dotyczace rozumu ludzkiego, tłum. B.J. Gawecki, t. 2, Warszawa 1955, s. 440-441).

Studia Philosophica Wratislaviensia 13, 2018 z. 3, (C) for this edition by CNS 
tetów czy ekspertów wiążą się poważne zagrożenia dla racjonalności argumentacji, ponieważ odpowiednie użycie bądź ocena poprawności argumentu z autorytetu wymaga zdolności rozpoznawania, jakie i czyje opinie można akceptować jako wiarygodne. Dlatego też wyrabianiu tych zdolności czy kompetencji należy poświęcać szczególną uwagę na kursach tak zwanego krytycznego myślenia czy praktycznej (racjonalnej) argumentacji.

Pretekstem dla podjęcia przeze mnie tego zagadnienia jest najnowsza książka Andrzeja Kisielewicza Logika i argumentacja. Praktyczny kurs krytycznego myśle$n i a^{3}$. Ta pomyślana jako podręcznik akademicki pozycja stanowi bez wątpienia cenny wkład w dość słabo zagospodarowany przez polskich autorów temat nauczania tak zwanego krytycznego myślenia (critical thinking). Jak zauważa sam Kisielewicz, rolę wprowadzania studentów w arkana racjonalnej argumentacji czy wnioskowania pozostawia się dziś często kursom logiki prowadzonym według klasycznych wzorców i podręczników, w których „,nacisk jest położony na formalne schematy wnioskowania [...] zupełnie oderwane od istoty logicznego myślenia i mało przydatne w praktyce"4. Podkreślając ograniczoną rolę logiki formalnej i pragnąc skupić się na praktycznej stronie argumentacji, A. Kisielewicz chciał równocześnie uniknąć tego, co, jak rozumiem, uważa za drugą skrajność, jaką stanowią niektóre anglosaskie wykłady logiki nieformalnej, które nie przemawiają do studentów nauk ścisłych (z myślą o których autor opracował swój podręcznik) między innymi ze względu na „brak konkretnych metod i konkretnej wiedzy”. Powstały podręcznik ma

posmak ścisłości i konkretności na tyle, na ile jest to możliwe w dziedzinie, która z natury nie jest ani jasna, ani ścisła, która rozważa znaczenia zdań w języku naturalnym oraz relacje miedzy niezupełnie ścisłymi twierdzeniami na temat rzeczywistości zewnętrznej ${ }^{6}$.

Przytaczam tu tę ,autoreklamę” z Wprowadzenia do omawianej książki, ponieważ uważam, że Kisielewiczowi w dużej mierze rzeczywiście udało się osiągnacć zamierzony cel. Ograniczając wykład formalnych reguł wnioskowania, przedstawił szereg dających się stosować w praktyce metod zarówno formułowania poprawnych, racjonalnych argumentów, jak i oceniania argumentów pod kątem rzetelności, wiarygodności, relewancji przesłanek do wniosków itp.

Z pełnym zrozumieniem, że opracowywanie tego rodzaju publikacji wiąże się z koniecznością dokonywania wyboru z bardzo dużej puli zagadnień — w rezultacie czego każdy, kto się podobnego zadania podejmuje, naraża się na zarzuty dotyczące pominięcia takich czy innych wątków - chciałbym mimo to wskazać zagadnienie (czy zestaw zagadnień), któremu podręcznik nie poświęcił w mojej opinii wystarczającej uwagi. Zgodnie bowiem z przyjętym przez autora rozumieniem terminu „krytyczne myślenie” (którego Logika i argumentacja ma być wykładem) obejmuje on ,zarówno logiczne myślenie, poprawne rozumowanie, logikę w tradycyjnym rozumieniu tego słowa, jak i sztukę logicznej argumentacji. Obejmuje on

\footnotetext{
${ }^{3}$ A. Kisielewicz, Logika i argumentacja. Praktyczny kurs krytycznego myślenia, Warszawa 2017.

4 Ibidem, s. 10.

5 Ibidem.

${ }^{6}$ Ibidem, s. 11.
} 
też krytyczną ocenę źródeł informacji i pewną postawę nieufności wobec cudzych i własnych ustaleń, charakterystyczną dla naukowców"7.

Tymczasem mam pewne wątpliwości, czy zaproponowany wykład w wystarczający sposób traktuje o zagadnieniach ujętych w drugiej części tej definicji. Zdolność oceny wiarygodności źródeł oraz oceny wiarygodności cudzych ustaleń, jest, jak już sugerowałem i co zaraz rozwinę, jedną z kluczowych kompetencji, jaką powinna posiąść dziś każda „krytycznie myśląca” osoba. Sprawy te zostały jednak potraktowane w Logice $i$ argumentacji w sposób co najmniej zdawkowy. Przykładowo w rozdziale I, w paragrafie 7.2 Wiarygodność źódet znajdujemy uwagi autora na temat problemów z oceną wiarygodności źródeł w dobie Internetu i związanej z tym medium demokratyzacją debaty publicznej, w ramach której każde ustalenie może być podważane. Znajdujemy tam także uwagi na temat problemów związanych z nieodpowiedzialnością samych naukowców nadużywających swojego autorytetu, świadomie lub nie. Jednak z uwag tych i ze stwierdzenia, że ,„[u]miejętność oceny wiarygodności różnych źródeł wymaga dziś odrębnego poznania i doświadczenia" niewiele wynika. Podobnie ma się sprawa z uwagą, że ,ganione jako chwyt erystyczny odwoływanie się do autorytetu [...] czy atak personalny [...] w pewnych przypadkach moga być jak najbardziej słuszne i prowadzace do prawidłowych logicznych [wniosków]"9; tym bardziej, że autor ostatecznie wymienia te argumenty w zestawieniu Wybranych błędów argumentacji ${ }^{10}$. Nie chcąc czynić z nieobecności tych zagadnień w podręczniku szczególnego zarzutu i z nadzieją, że pierwsze wydanie Logiki $i$ argumentacji nie będzie ostatnim, chciałbym zwrócić uwagę na ich wagę i potrzebę uwzględniania ich w kursach krytycznego myślenia.

Dopowiem jeszcze, że poniższe uwagi formułuję z perspektywy dydaktyka (humanisty) na uczelni technicznej, ogólnie zainteresowanego nauczaniem studentów krytycznego myślenia, jak i czynieniem użytku z opracowanego przez Kisielewicza podręcznika.

$* * *$

Poruszane w dalszej części artykułu zagadnienia składają się razem na bardzo szeroki temat, na którego wyczerpujące omówienie nie ma tutaj miejsca. W związku z tym przed przystąpieniem do dalszych rozważań chciałbym nieco dokładniej określić ich zakres. Przede wszystkim przedmiotem mojej wypowiedzi będzie odwoływanie się do autorytetów w ,argumentacji logicznej” w rozumieniu Kisielewicza, to jest argumentacji, której celem jest ,[...] dochodzenie do prawdy lub racjonalnego stanowiska odwołującego się wyłącznie do rozumu"11 — przy czym, ze względu na własne preferencje terminologiczne, będę posługiwał się pojęciem ,argumentacji

\footnotetext{
7 Ibidem, s. 15.

8 Ibidem, s. 35.

${ }^{9}$ Ibidem, s. 189 (cytowane zdanie niestety urywa się wskutek błędu edytorskiego).

10 Zob. ibidem, s. 190-191

11 Ibidem, s. 17.
} 
racjonalnej"12. Nie będą mnie zatem interesować retoryczne czy erystyczne aspekty argumentacji, choć warto zwrócić uwagę, że stosowanie określonych strategii retorycznych bynajmniej nie musi oznaczać zarzucania racjonalności argumentacji ${ }^{13}$.

Kolejne ważne dookreślenie wiąże się z rodzajem autorytetu, o jakim będzie tutaj mowa. Pojęcie autorytetu jest bowiem szerokie i odnosić się może do postaci autorytetu w różnych sferach życia, zarówno wiedzy czy kompetencji naukowych, jak i postaw moralnych itp. W tym, co następuje, interesować mnie będzie wyłącznie autorytet rozumiany jako ekspert w jakiejś dziedzinie czy dyscyplinie naukowej. Mówiąc o argumencie z autorytetu, będę miał zatem na myśli jego określony podtyp: argument z opinii eksperta. Przy czym warto zwrócić uwagę, że autorytatywności (czy eksperckości) jakiejś opinii nie nadają wyłącznie odwołania do osób, które ją wygłosiły, lecz również do źródeł, w których była głoszona ${ }^{14}$. Z tego też powodu łączyć będę problem oceny wiarygodności autorytetu (eksperta) z problemem oceny wiarygodności źródła informacji. Wreszcie, w nawiązaniu do rozróżnienia zaproponowanego niegdyś przez Józefa Bocheńskiego, interesować mnie będzie figura autorytetu epistemicznego, a nie deontycznego ${ }^{15}$.

\section{O konieczności odwoływania się do autorytetów}

Argument z autorytetu, jak wspomniałem, klasyfikowany był często jako błąd w rozumowaniu. Także i dziś powszechnie pojawia się on w popularnych zestawieniach „błędów logicznych” czy „błędów w argumentacji”, jakie można znaleźć w Internecie i w podręcznikach argumentacji. W przeszłości za słusznością takiej klasyfikacji przemawiały co najmniej dwa powody. Po pierwsze argument z autorytetu wykorzystywany jest często jako chwyt erystyczny służący przekonaniu odbiorcy do określonego twierdzenia czy poglądu nie racjami, lecz poprzez postawienie go w sytuacji, w której nie śmie on wystąpić przeciwko opinii osoby darzonej dużym poważaniem. Ma to swoje odzwierciedlenie w łacińskim odpowiedniku polskiego „,argumentu z autorytetu”, czyli argumentum ad verecundiam — dosłownie „argu-

12 Pod pojęciem „argumentacji logicznej” można rozumieć argumentację, która daje się przedstawić w formie wnioskowania dedukcyjnego, w którym przejście od przesłanek do wniosku odbywa się wyłącznie w oparciu o reguły logiki formalnej. Ponieważ, jak była o tym mowa, Kisielewicz z dużym sceptycyzmem odnosi się do kwestii użyteczności logiki formalnej dla celów praktycznej argumentacji, rozszerza pojęcie logicznej argumentacji w przywołany wyżej sposób. Co prawda postrzegam tę sprawę raczej w kategoriach preferencji terminologicznych, o które nigdy nie warto kruszyć kopii, niemniej wydaje mi się, że propozycja autora Logiki $i$ argumentacji jest mnożeniem pojęć ponad potrzebę, gdyż po rozszerzeniu zakresu pojęcia „argumentacji logicznej”, potrzebujemy nowego pojęcia dla określenia argumentacji logicznej w tradycyjnym znaczeniu słowa „logika”. Tymczasem pojęcie „argumentacji racjonalnej” uwzględniać może, jak mi się wydaje, oba rozumienia „logiczności” — to formalne i to, którym operuje A. Kisielewicz.

13 Zob. np. M. Koszowy, K. Budzyńska, Strategie retoryczne, techniki komunikacyjno-poznawcze, błędy i sofizmaty, Warszawa 2015.

14 To jest „Albert Einstein powiedział $X$, więc $X$ jest prawdziwe” jest tego samego rodzaju argumentem z autorytetu (z opinii eksperta), co „W artykule w Nature napisano, że $X$, więc $X$ prawdziwe”.

15 Zob. J.M. Bocheński, Co to jest autorytet?, [w:] idem, Logika i filozofia. Wybór pism, Warszawa 1993, s. $187-324$. 
ment do nieśmiałości"16. Po drugie, stan wiedzy naukowej aż do, powiedzmy, XVIII wieku pozwalał każdej wykształconej osobie wyrabiać sobie własne opinie na wiele spraw przy pomocy, jeśli nie własnych badań, to własnych rozumowań i analiz ${ }^{17}$. Pierwszy z tych powodów pozostanie oczywiście zawsze aktualny, co, jak można przypuszczać, sprawia właśnie, że argument z autorytetu jest tak powszechnie kategoryzowany jako błąd ${ }^{18}$. Co się jednak tyczy drugiego powodu, stracił on dawno na aktualności wraz z rozwojem nauk i postępującą w nich specjalizacją. Trywialną obserwacja jest stwierdzenie, że charakter współczesnej wiedzy naukowej sprawia, że specjalistą nie jest się już nawet w jednej określonej dyscyplinie naukowej, lecz jedynie w jednej lub niewielu subdyscyplinach — czy wręcz jedynie w zakresie specyficznego obszaru prowadzonych przez siebie badań. Tym samym postulowanie jako kryterium racjonalnej argumentacji opierania się wyłącznie na własnych rozumowaniach (na przykład od danych empirycznych do twierdzeń, za którymi maja przemawiać) można w najlepszym razie uznać za fikcję literacką. Zwyczajnie nie jesteśmy dziś w stanie wyrobić sobie „własnej opinii” na wiele spraw bez odwołania się do opinii ekspertów. Tyczy się to w każdym razie wskazanego wcześniej kontekstu, w którym argumentacja za jakimś twierdzeniem wymaga odwołania się do aktualnego stanu wiedzy naukowej. Jednak tego rodzaju potrzeba pojawia się obecnie w bardzo szerokim spektrum zagadnień, w tym w dyskusjach, które wielu uznałoby za spory światopoglądowe, etyczne, estetyczne itp. ${ }^{19}$

W takiej sytuacji staje się jasne, że jedną z podstawowych kompetencji, jaką powinien nabyć każdy, kto chce być w stanie wyrabiać sobie racjonalne opinie na wiele spraw jest zdolność odróżniania opinii autorytetów, które można zaakceptować jako przesłanki w racjonalnej argumentacji czy racjonalnym wnioskowaniu, od takich, które należy odrzucić. O braku takich kompetencji wśród zauważalnego odsetka ludzi świadczy niezwykła popularność ewidentnie pseudonaukowych po-

16 To właśnie na ten aspekt argumentum ad verecundiam kładł nacisk Locke (zob. przyp. 2).

17 Jeszcze uczeni działający na przełomie XIX i XX wieku specjalizowali się często w kilku różnych dziedzinach naukowych. Wspomnieć tu można taką postać, jak H. Poincaré (1854-1912), który zajmował się w zasadzie wszystkimi wyróżnianymi ówcześnie dziedzinami matematyki, fizyką, astronomią, co nie przeszkodziło mu pozostawić po sobie niezwykle wnikliwych prac z filozofii nauki (przy tym z pierwszego wykształcenia był inżynierem górnictwa).

${ }^{18}$ Innego rodzaju przyczyna utrzymywania się takiej klasyfikacji ma swoje źródło w tradycji. Jak zauważają Koszowy i Budzyńska: „,...] techniki retoryczne określane ogólną nazwą argumenta ad tradycyjnie były utożsamiane z technikami błędnymi [...]. Przyczyn takiego stanu rzeczy można szukać w tym, że tradycyjna lista owych technik została sporządzona na podstawie arystotelesowskiej listy dowodów sofistycznych (wyłożonej w dziele $O$ dowodach sofistycznych. [...] Lista arystotelesowska wraz z jej średniowiecznymi rozszerzeniami stanowią podstawę dla standardowego ujęcia niepoprawnych technik retorycznych, które zdominowało anglosaskie podręczniki logiki" (M. Koszowy, K. Budzyńska, op. cit, s. 6). Przy czym jako pierwszy opis argumentum ad verecundiam autorzy ci wskazują (ibidem, s. 142) fragment Rozważań... Locke'a cytowany w przyp. 2.

19 Przyjmuję, że z dyskusją czy sporem „czysto światopoglądowym” lub „czysto etycznym” mamy do czynienia wtedy, kiedy wszystkie strony zgadzają się co do ,jest”, lecz nie co do „powinien”. Tymczasem w wielu ważnych współczesnych światopoglądowych i etycznych debatach — dotyczących na przykład kwestii dopuszczania do użycia takich czy innych nowych technologii — dyskusje toczą się na obu poziomach, w celu zaś ustalenia tego, co ,,jest”, konieczne jest odwoływanie się do ustaleń naukowych. 
glądów ${ }^{20}$ — od wiary w skuteczność homeopatii, przez przekonania o szkodliwości szczepień czy o zagrożeniach ze strony GMO, po zaprzeczanie globalnemu ociepleniu. W tych i wielu podobnych przypadkach mamy do czynienia z niesamowita wręcz rozbieżnością między opiniami ekspertów a opiniami ogółu społeczeństwa. Co więcej, poglądy takie przenikają nieraz do instytucji, po których spodziewalibyśmy się, że z definicji stać będą na straży standardów naukowości. Za jeden przykład niech posłuży fakt otworzenia w 2014 roku na Śląskim Uniwersytecie Medycznym kierunku studiów podyplomowych „,homeopatia w medycynie niekonwencjonalnej i farmacji”"21 (inny przykład opisuję obszernie poniżej). Warto przy tym zwrócić uwagę, że w przypadku wielu tego rodzaju pseudonaukowych poglądów nie mamy do czynienia z kwestionowaniem samej nauki czy „metody naukowej” — jak to ma miejsce na przykład w przypadku „medycyny naturalnej”, którą propagatorzy reklamują często jako alternatywną względem medycyny konwencjonalnej, przeciwstawiając przy tym naukę innym sposobom poznawania rzeczywistości lecz można je nazwać pseudonaukowymi właśnie dlatego, że dosłownie udaja naukę, co widoczne jest między innymi w retoryce powoływania się na wyniki badań naukowych przez ich propagatorów ${ }^{22}$.

${ }^{20}$ Piszę „,ewidentnie pseudonaukowych”, ponieważ z perspektywy ustaleń współczesnej filozofii i metodologii nauk nie da się wyznaczyć wyraźnej granicy między nauką a pseudonauką. Jeśli zapoczątkowane w pierwszej połowie XX wieku poszukiwania uniwersalnego kryterium demarkacji doprowadziły do jakiejś konkluzji, to brzmi ona: nie istnieje jedno i uniwersalne kryterium naukowości (zob. np. L. Laudan, Zgon problemu demarkacji, tłum. A. Koterski, [w:] Z badań nad prawda, nauka i poznaniem, Z. Muszyński (red.), Lublin 1998, s. 63-79). Nie musi to oczywiście zaraz oznaczać, że nie dysponujemy żadnymi narzędziami do oceniania różnych poglądów, teorii czy programów badawczych pod kątem „naukowości”, lecz dziś czynimy to ze świadomością, że z jednej strony nie istnieje coś takiego jak jeden wzór naukowości, z drugiej zaś, że nie istnieje jeden typ pseudonauki. Współcześni badacze problemu mówią raczej o pewnym spektrum biegnącym od „dobrej nauki” przez naukę „złą” czy „patologiczną” po różnego typu „pseudonaukę”. Na temat współczesnego podejścia do problemu demarkacji zob. np. artykuły zgromadzone w tomie: Philosophy of pseudoscience. Reconsidering the Demarcation Problem, M. Pigluicci, M. Boudry (eds.), Chicago-London 2013.

${ }^{21}$ Kierunek szczęśliwie zlikwidowano w 2016 roku. Przy czym same preparaty homeopatyczne pozostaja umocowane w polskim prawodawstwie - zob. art. 2. pkt 29. Ustawy Prawo Farmaceutyczne, gdzie definiowany jest ,produkt leczniczy homeopatyczny”.

${ }^{22} \mathrm{Na}$ przykład rzecznicy homeopatii, w przeciwieństwie do propagatorów niektórych innych metod tak zwanej medycyny niekonwencjonalnej, nie odrzucają nauki, lecz twierdzą, że skuteczność ich metody znajduje potwierdzenie w badaniach naukowych. Ciekawa jest historia związana z opublikowaniem w 1988 roku przez Nature artykułu zgłoszonego przez homeopatę (i immunologa) J. Benveniste'a, opisującego wyniki badań rzekomo potwierdzających skuteczność homeopatii. Redaktor naczelny pisma zdecydował się na przyjęcie tekstu do publikacji, licząc na otworzenie naukowej debaty na ten temat. Jednak mimo powszechnej krytyki ze strony ekspertów — obejmującej powtórzenie opisanego w artykule eksperymentu przez grupę badaczy z londyńskiego University College zwieńczonego wnioskiem: „dane w żadnym aspekcie nie zgadzają się z opublikowanymi wcześniej twierdzeniami” — „Homeopaci — jak referuje R. Park — w dalszym ciągu przywołują artykuł Benveniste'a jako dowodzący prawa nieskończenie małych dawek oraz by preparować ogólnikowe teorie wyjaśniające ten niesamowity rezultat"; R. Park, Voodoo Science. The Road from Foolishness to Fraud, Oxford 2000, s. 55 (52-58). O tym, że dalej tak jest, można się przekonać na przykład tutaj: http://www.lekarzehomeopaci.pl/ homeopatia/8-homeopatia/246-lek-homeopatyczny-to-nie-placebo-lecz-biofizyczna-metoda-przywracan ia-zdrowia (dostęp: 15.03.2018).

Studia Philosophica Wratislaviensia 13, 2018 z. 3, (C) for this edition by CNS 
Mimo utraty zaufania do nauki, z jaką mieliśmy do czynienia w ciągu ostatnich kilkudziesięciu lat, wiele osób wciąż traktuje opinie ekspertów, rozumianych jako badacze zajmujacy się zawodowo określonymi zagadnieniami, jako autorytatywne i najbardziej wiarygodne. Przykładowo w przeprowadzonym w 2015 roku w USA badaniu dotyczącym wiedzy konsumentów na temat żywności opartej na GMO $84 \%$ respondentów opowiedziało się za obowiązkowym oznaczaniem produktów zawierających składniki modyfikowane genetycznie, lecz równocześnie $65 \%$ respondentów stwierdziło, że podejmowanie związanych z tym decyzji należy pozostawić ekspertom $^{23}$. Sugeruje to, że często w sprawach, w których mamy już jakieś opinie, jesteśmy mimo to świadomi niedostatków naszej wiedzy i/lub braku kompetencji do rzetelnej oceny wyników badań naukowych i chętnie polegamy na opinii ekspertów. To, na ile jesteśmy zdolni odróżniać ekspertów od pseudoekspertów, to oczywiście inne pytanie.

\section{Pseudoautorety za pseudonauką i ryzyko Internetu ziszczone}

Przypomnijmy dla porządku, że przedmiotem obecnych rozważań jest postać autorytetu jako eksperta, którego można uznawać za źródło miarodajnych opinii na tematy związane z obecnym stanem wiedzy naukowej. Kontekstem dyskusji jest zaś nauczanie krytycznego myślenia studentów (w szczególności studentów nauk ścisłych). Pojawia się więc pytanie o strategie oceny wiarygodności autorytetów i źródeł informacji, jakimi się ogólnie oni posługują ${ }^{24}$. Kiedy pytam studentów (uczelni technicznej, na której prowadzę zajęcia) o ich strategie rozpoznawania autorytetów (ekspertów), otrzymuję na ogół odpowiedź wskazującą na kierowanie się dwoma podstawowymi kryteriami: dziedziną i poziomem wykształcenia domniemanego autorytetu (jednocześnie studenci sami z siebie podnoszą często jako problem roszczenia sobie kompetencji ekspertów przez różnego rodzaju celebrytów i idoli). Ogólna intuicja jest zatem taka, że opinię osoby $X$ na temat zagadnienia $k$ można uznać za autorytatywną/wiarygodną, jeśli $X$ jest wykształcony w i/lub zajmuje się zawodowo dziedziną czy dyscypliną, pod którą podpada $k$, i jednocześnie można ją uznać za tym bardziej wiarygodną, im wyższy jest tytuł naukowy, jakim legitymuje się $X$. Jednak poza tą intuicją studenci rzadko są w stanie wskazać bardziej precyzyjne metody czy strategie dalszej oceny wiarygodności ekspertów - czy szerzej, oceny wiarygodności źródeł, w której to kwestii świadomości

${ }^{23}$ Zob. B.R. McFadden, J.L. Lusk, What consumers don't know about genetically modified food, and how that affects beliefs, „FASEB Journal” 30 (2016), s. 3091-3096, http://www.fasebj.org/doi/ full/10.1096/fj.201600598 (dostęp: 15.02.2018). Ponura ciekawostka: w tym samym badaniu $80 \%$ respondentów opowiedziało się za obligatoryjnym oznaczaniem żywności zawierającej DNA.

${ }^{24}$ Oczywiście to, na ile zdolność oceny wiarygodności autorytetów i źródeł informacji wśród studentów określonych stopni i osób z wyższym wykształceniem różni się od zdolności pozostałych członków społeczeństwa stanowi samo w sobie ciekawe pytanie, które wymagałoby osobnego rozważenia i na które mogłyby po części odpowiedzieć odpowiednie badania empiryczne. Ponieważ nie udało mi się znaleźć opisów takich badań, w powyższych rozważaniach opieram się na własnych rozmowach na te tematy ze studentami (uczelni technicznej) różnych poziomów studiów i różnych kierunków. 
różnej wagi rozmaitych publikacji często nie towarzyszy umiejętność wskazania, jak tę wagę można oceniać. O poprzestawaniu na tego rodzaju ogólnych intuicjach świadczyć może dość powszechne — choć oczywiście częściowo zależne od zaawansowania studentów - niezrozumienie pojęć niezbędnych nieraz do oceny wiarygodności opinii czy informacji, na przykład tego, czym jest metaanaliza, „drapieżne pisma” (predatory journals), czy też wiedzy o tym, gdzie i jak weryfikować informacje o ekspertach, szukać ich publikacji i wreszcie oceniać wiarygodność wydawnictw czy pism, w których je zamieszczali.

Tymczasem strategia polegania na dziedzinie i tytule naukowym domniemanego autorytetu może być mocno zwodnicza. Po części wiąże się to z problemem, nierzadkiego niestety, braku odpowiedzialności naukowców wypowiadających się autorytatywnie na tematy wykraczające poza ich kompetencje naukowe. Jest to zjawisko najbardziej dostrzegalne w przypadku niektórych „ekspertów telewizyjnych” czy „naukowców-celebrytów”, którzy chętnie służą opiniami na każdy temat, niezależnie od tego, czy mieści się on w zakresie ich specjalizacji ${ }^{25}$. Poważniejszy, przynajmniej z perspektywy obecnych rozważań, wydaje się jednak problem naukowców wypowiadających się na tematy leżące poza zakresem ich kompetencji, które jednak z perspektywy laika mogą się wydawać w nich mieścić (wrócę do tego problemu za moment).

Drugi problem wiąże się z nadmiarem informacji (a więc i „opinii eksperckich”), o jaki potyka się dziś każdy, kto poszukuje informacji przy pomocy Internetu. Pod koniec lat dziewięćdziesiątych w felietonie Ryzyko Internetu Stanisław Lem wyliczał zagrożenia, jakie jego zdaniem wiążą się z upowszechnianiem się tej wówczas jeszcze raczkującej technologii. Jednym z nich był nadmiar informacji przy jednoczesnym braku jej selekcji pod kątem merytorycznej poprawności i aktualności. Jak pisał:

Internet to sieć, która niczego nie rozumie, jeno informacje przesyła i strony ze sobą łączy, zaś wzrastająca na całym świecie ilość „ekspertów”, którzy chcąc się „wykazać”, produkują mało albo nic nie warte wyniki swoich przemyśleń jako „nowe hipotezy naukowe”, jest tym samym, czym piasek i muł, który z wielkich zbiorników wodnych kieruje się ku turbinom i gdyby nie specjalne urządzenia filtrujące, wnet by wszystkie turbiny ,zatkało”. Lecz Internet nie może odróżnić informacyjnego ziarna, którego w nim jest mało, od informacyjnych plew $[\ldots]^{26}$.

Dziś jest już oczywiste, że obawa ta się w dużej mierze ziściła. Internet stał się forum, na którym każdy może wypowiadać się autorytatywnie na dowolny temat, a jeśli tylko uda mu się dotrzeć do odpowiedniego grona odbiorców, jego opinie będą się rozpowszechniać. Internet nie jest dziś co prawda taki ślepy, lecz dostrzega i odsiewa nie to, czego S. Lem przypuszczalnie by oczekiwał. Wyszukiwarki internetowe pozycjonują bowiem wyniki wyszukiwań nie podług ich merytorycznej poprawności czy wiarygodności, lecz popularności. W rezultacie, choć istnieje

25 „Przypadłość” ta dotyka również laureatów Nagrody Nobla. Na portalu RationalWiki można znaleźć opis „,choroby noblowskiej” rozumianej jako „,tendencja laureatów Nagrody Nobla do popierania lub prowadzenia »badań« w obszarach pseudonauki w swoich późniejszych latach, generalnie (choć nie zawsze) po zdobyciu szanowanej nagrody lub jakimś prawdziwie naukowym osiągnięciu"; https:// rationalwiki.org/wiki/Nobel_disease (dostęp: 15.02.2018).

26 S. Lem, op. cit., s. 9-10. 
w Internecie szereg rzetelnych źródeł informacji, niekoniecznie są one tymi, do których docieraja przeciętni jego użytkownicy.

Opisany poniżej przykład ukazuje powagę zarówno problemu jakości informacji dostępnych w Internecie, jak i problemu nieodpowiedzialności ekspertów wygłaszajacych autorytatywne opinie poza zakresem swoich specjalizacji — i tym samym wagę wyrabiania wśród studentów zdolności oceny wiarygodności źródeł i opinii autorytetów.

\section{Przykład: Internet vs GMO}

Przykład ten będzie opisem prostego „doświadczenia” (czytelnik może je łatwo powtórzyć), które przeprowadziłem jesienią 2017 roku i które kilkakrotnie powtarzałem ze studentami w ramach prowadzonych zajęć dydaktycznych. Polegało ono na próbie wcielenia się w przeciętnego użytkownika Internetu, szukającego odpowiedzi na pytanie: Czy genetycznie modyfikowane rośliny są szkodliwe dla zdrowia i środowiska naturalnego? Dla pełnego zobrazowania problemu, przytoczę opis przebiegu doświadczenia w szczegółowy sposób.

Otóż poszukiwanie odpowiedzi na postawione wyżej pytanie rozpocząłem od wpisania w wyszukiwarkę Google hasła „szkodliwość GMO” (bez cudzysłowu). Wyszukiwanie przyniosło 112 tysięcy wyników. Nagłówki pierwszych kilku sugerowały, że odnoszą się do artykułów oferujących twierdzącą odpowiedź na postawione pytanie. Kilka kolejnych sugerowało treści przeciwne - na drugą stronę wyników wyszukiwania, jak znaczna większość użytkowników Internetu ${ }^{27}$, nie zdecydowałem się zaglądać. Ponieważ, jak wiele osób, najwyżej cenię sobie opinie ekspertów, a za tych z kolei uważam aktywnych naukowców legitymujących się tytułami naukowymi, moją uwagę od razu przykuł nagłówek pierwszego ${ }^{28}$ wyniku: „Apel Polskiej Akademii Nauki [sic!] w sprawie szkodliwości GMO”. Po otwarciu odnośnika trafiłem na stronę, której wygląd i inne anonsowane na niej tematy mogłyby nawet co mniej krytycznych użytkowników Internetu zachęcić do poszukania innego źródła, lecz najwyraźniej dzieje się inaczej, skoro wynik ten jest tak wysoko pozycjonowaną odpowiedzią na, przypuszczalnie, nie takie niecodzienne zapytanie. Być może za tę wysoką pozycję odpowiada właśnie autorytet Polskiej Akademii Nauk, na którą powołuje się autor tekstu, pisząc w lidzie:

Komitet Ochrony Przyrody Polskiej Akademii Nauk (PAN) wystosował bezprecedensowy apel w sprawie zagrożenia zdrowia i środowiska ze strony GMO. Eksperci PAN wskazują na realne zagro-

27 O tym, że szukając informacji, użytkownicy Internetu (czy, konkretniej, wyszukiwarki Google) nie wychodzą zwykle poza pierwszą stronę wyników wyszukiwań, a nawet poza pierwszych kilka wyników, świadczą analizy danych Google'a (zob. np. https://chitika.com/2013/06/07/the-value-of-google-result-positioning-2/), jak również niektóre badania; zob. np. A.J.A.M. van Deursen, J.A.G.M. van Dijk, Using the Internet: Skill related problems in users' online behavior, „Interacting with Computers" 5-6 (2009), s. 393-402.

28 Był to pierwszy wynik dla wskazanego hasła w polskiej wersji wyszukiwarki Google w październiku 2017 roku. Dla pewności sprawdziłem to wyszukanie na różnych komputerach i różnych sieciach, za każdym razem otrzymując te same wyniki. Obecnie (luty 2018 roku) wynik ten przy wyszukaniu tego samego hasła ma drugą pozycję. 
żenie bioróżnorodności Polski ze strony wprowadzanych do środowiska organizmów modyfikowanych genetycznie $(\mathrm{GMO})^{29}$.

Jak dowiadujemy się z ,artykułu”, eksperci z PAN — nazwani „najlepszymi polskimi specjalistami ochrony środowiska” — ostrzegają przed „poważnymi i dalekosiężnymi konsekwencjami" uwalniania organizmów genetycznie modyfikowanych do środowiska. Dowiadujemy się również o badaniach zagranicznych naukowców, zgodnie z którymi „nie ma już żadnych wątpliwości — GMO jest szkodliwe dla ludzi i zwierząt".

Dla bardziej dociekliwego i być może powątpiewającego w wiarygodność przedstawionych informacji użytkownika dostępny jest odsyłacz do źródła. Niestety, nie działa. Jednak informacja o apelu ekspertów z PAN bynajmniej nie została wyssana z palca. Krótkie poszukiwania przy pomocy wyszukiwarki Google ujawniają, że KOP PAN wystosował co najmniej dwa apele w sprawie uprawiania roślin genetycznie modyfikowanych w Polsce. W pierwszym z tych dokumentów, datowanym na 28 stycznia 2008 roku i zatytułowanym ,Stanowisko Komitetu Ochrony Przyrody PAN w sprawie uprawiania w Polsce roślin genetycznie zmodyfikowanych (GM)"’30, możemy przeczytać między innymi (w punkcie „Wobec zagrożeń”):

Komitet Ochrony Przyrody PAN, jako interdyscyplinarny zespół badaczy, w którego skład wchodzą zarówno ekolodzy, jak i specjaliści zajmujący się innymi aspektami nauk środowiskowych, pragnie kolejny raz zwrócić uwagę na następujące fakty:

1. Istnieją rozpoznane już bezpośrednie i pośrednie zagrożenia ekologiczne ze strony GMO, których dalekosiężne i wielowymiarowe konsekwencje wymagają zbadania i oszacowania,

2. Istnieją analogiczne dowody, anonsowane w najpoważniejszych czasopismach naukowych i rzetelnych opracowaniach syntetycznych, na negatywne skutki zdrowotne upraw i spożywania pokarmów tworzonych na bazie GMO,

3. Wykazano jawnie negatywne skutki społeczno-ekonomiczne wprowadzenia GMO w Polsce,

4. Wszystkie województwa, głosem swych przedstawicieli, wyraziły jasno wolę pozostania strefami wolnymi od GMO,

5. Większość polskich konsumentów w sposób nie budzący wątpliwości stwierdza, że nie życzy sobie żywności zawierającej w swym składzie GMO,

6. Wielu wybitnych uczonych polskich, zajmujących się różnymi aspektami GMO, wypowiadało się jednoznacznie i kategorycznie przeciwko wprowadzeniu do uprawy przy obecnym stanie wiedzy organizmów zmodyfikowanych genetycznie.

Biorąc pod uwagę wszystkie wyżej wymienione przesłanki, Komitet Ochrony Przyrody Polskiej Akademii Nauk dwukrotnie wypowiadał się przeciwko wprowadzeniu do uprawy, czy też uwalnianiu do środowiska w inny sposób, organizmów zmodyfikowanych genetycznie. Wskazywał także na konieczność wprowadzenia odpowiednio długiego moratorium, w trakcie którego należy przeprowadzić niezbędne badania pozwalające ustalić, czy, a jeżeli tak, to w jakim stopniu i w jakich przypadkach oraz przy jakich środkach bezpieczeństwa, można będzie dopuścić uprawę GMO w Polsce.

Z dokumentu dowiadujemy się też o ,kampanii medialnej wsparcia dla GMO”, w którą ,wciągnięto biotechnologów, starając się równocześnie nie dopuścić do głosu środowisk niezależnych specjalistów z innych dyscyplin" oraz o braku obiektywizmu w doniesieniach prasowych, czego przykładem ma być między innymi

${ }^{29}$ https://www.vismaya-maitreya.pl/teorie_spiskowe_apel_polskiej_akademii_nauki_w_sprawie_szkodliwosci_gmo.html (dostęp: 15.02.2018).

${ }^{3} 0$ Dokument ten można znaleźć pod adresem: http://www.botany.pl/kop-pan/stanowiska/GMO2. pdf (dostęp: 15.02.2018). 
powoływanie się w nich na badania bez precyzowania źródła. Całość kończy się zaś szeregiem zaleceń, mających na celu zakazanie czy też opóźnienie (do czasu przeprowadzenia dalszych badań) dopuszczenia upraw roślin GM w Polsce. Pod apelem widnieje podpis: Prof. dr hab. Zbigniew Mirek, Przewodniczący Komitetu Ochrony Przyrody PAN.

Drugi z dokumentów, datowany na 1 lutego 2010 roku, zatytułowany jest „Oświadczenie Komitetu Ochrony Przyrody PAN w wprawie uwalniania do środowiska organizmów modyfikowanych genetycznie (GMO): »Konieczność moratorium i wielostronnych badań «"31. W dokumencie tym KOP „wzmacnia swoje stanowisko z dnia 28 stycznia 2008 roku w sprawie GMO”, czyli stanowisko z przywołanego wyżej apelu. Ponownie stwierdza się, że dopuszczenie do uprawiania roślin genetycznie modyfikowanych w Polsce nie tylko stanowi realne zagrożenie ekologiczne, lecz również niesie z sobą negatywne skutki społeczno-ekonomiczne oraz zdrowotne. Całość kończy zaś apel o „[r]ygorystyczne przestrzeganie obowiązującego w sprawie GMO prawa i nie podejmowanie obecnie działań na rzecz jego liberalizacji” oraz o „,[p]ilne wprowadzenie 15-letniego moratorium na uprawy oraz uwalnianie do środowiska GMO" do czasu przeprowadzenia dalszych badań i stworzenia narzędzi monitorowania wpływu upraw roślin GM na środowisko. Pod apelem ponownie widnieje podpis profesora doktora habilitowanego Zbigniewa Mirka, Przewodniczącego Komitetu Ochrony Przyrody PAN.

Oba dokumenty już same w sobie budzą poważne wątpliwości co do rzetelności ich autora lub autorów i tym samym wiarygodności prezentowanych informacji. Przede wszystkim, chociaż w pierwszym z dokumentów wielokrotnie spotykamy sformułowania w rodzaju „wykazano”, ,istnieją dowody" czy „wyniki badań”, dokument w żadnym miejscu nie precyzuje, o jakie dokładnie badania chodzi, nie mówiąc już o odesłaniu do źródeł — co, jak widzieliśmy, nie przeszkadza autorowi czy autorom zarzucać tego samego doniesieniom prasowym. Jedynymi wymienionymi w dokumencie pozycjami polecanymi czytelnikom dokumentu jako źródło wiedzy o GMO są natomiast książka J. Smitha Nasiona kłamstwa (tytuł mówi sam za siebie) oraz strona gmwatch.org ${ }^{32}$. W tym momencie chciałbym skupić się jednak na innym pytaniu, mianowicie: czy autor lub autorzy tego dokumentu są ekspertami w zakresie zagadnień, o których się w roli autorytetów wypowiadają. Jak już była o tym mowa, wyrabiając sobie opinię na jakiś temat, szukamy często opinii ekspertów, a za takich chętnie uznajemy utytułowanych naukowców stosownych dziedzin czy dyscyplin, nieraz również z odpowiednimi afiliacjami. Tytuł naukowy osoby podpisanej pod oboma apelami (prof. dr hab.) oraz jej afiliacja (PAN) sugerują, że mamy bez wątpienia do czynienia z ekspertem. Należy zwrócić jednak uwagę, że zrozumienie i ocena wyszczególnionych wyżej zagrożeń ze strony GMO wymaga eksperckiej wiedzy z więcej niż jednej dyscypliny. Dotyczy

\footnotetext{
${ }^{31}$ Dokument ten można znaleźć pod adresem: http://www.botany.pl/kop-pan/stanowiska/GMO3. pdf (dostęp: 15.02.2018).

${ }^{32}$ Pierwsza z tych pozycji to książka autorstwa aktywisty anty-GMO (byłego nauczyciela tańca z tytułem MBA uzyskanym na Maharishi International University [renomę uczelni pozostawiam do sprawdzenia dociekliwym Czytelnikom]), druga zaś to strona organizacji GMWatch, również z założenia zajmującej się walką z rozpowszechnianiem upraw roślin GM.
} 
to już samych tytułowych zagrożeń związanych z uwalnianiem organizmów GM do środowiska, których rzetelna ocena wymaga albo doświadczenia z prowadzenia badań z zakresu tego konkretnego zagadnienia, albo wiedzy eksperckiej z więcej niż jednej specjalizacji — nie tylko ekologii, lecz także genetyki (w uproszczeniu ${ }^{33}$ ). Natomiast w apelu, jak widzieliśmy, mowa jest także o zagrożeniach dla zdrowia ze strony żywności produkowanej na bazie GMO oraz o negatywnych skutkach społeczno-ekonomicznych związanych z uprawianiem roślin GM. Pytanie o zakres specjalizacji podpisanego pod apelem eksperta nasuwa się samo. Jak zaś można dowiedzieć się z jego biogramu, jest on botanikiem zajmującym się systematyką roślin, florystyką, fitogeografią, historią botaniki, ochroną przyrody i popularyzacją wiedzy botanicznej. W wykazie jego publikacji, przynajmniej jeśli wnosić po samych tytułach, dominują prace z zakresu pierwszych trzech obszarów, brak jest zaś prac dotyczących zagadnień, o których mowa w przywołanych dokumentach ${ }^{34}$. Już samo to może sugerować, że Przewodniczący KOP wychodzi poza zakres swojej kompetencji już w samym tylko podstawowym temacie obu apelów - co się zaś tyczy pozostałych zagadnień, nie ma wątpliwości, że tak jest. Ponieważ jest on jedyną osobą podpisaną pod apelami, nie da się stwierdzić, czy dokumenty te zostały przygotowane przez wszystkich ówczesnych członków KOP, niektórych z nich, czy wreszcie jedynie przez samego podpisanego. Okazuje się to mieć jednak drugorzędne znaczenie po zapoznaniu się ze specjalizacjami i przedmiotami badań pozostałych ówczesnych członków Komitetu, które bynajmniej nie uzupełniają się ze specjalizacjami Przewodniczącego na tyle, aby uznać, że mamy do czynienia interdyscyplinarnym zespołem kompetentnym do rzetelnej oceny zagrożeń związanych z uwalnianiem roślin GM do środowiska (a tym bardziej pozostałych wskazywanych zagrożeń) ${ }^{35}$. Oczywiście, jako biolodzy członkowie tego gremium maja teoretycznie dużo wyższe kompetencje do oceny głównych wskazanych w apelu zagrożeń środowiskowych ze strony upraw GMO niż nie-biolodzy ${ }^{36}$. Ponieważ jednak nie wypowiadają się na temat swoich własnych ustaleń, można by oczekiwać wskazania, na jakich ustaleniach opierają swoje opinie. Tego jednak nie znajdujemy z żadnym z dokumentów (w drugim z nich czytamy: „Komitet Ochrony Przyrody

33 Wymienianie dyscyplin czy subdyscyplin w takim kontekście jest pewnym uproszczeniem, bowiem specjalizacja w naukach przyrodniczych — i biologia nie jest tutaj wyjątkiem, wręcz przeciwnie — jest dziś tak głęboka, że z punktu widzenia samych badaczy wyszczególnianie i definiowanie dyscyplin i subdyscyplin ich nauk stało się w dużej mierze bezprzedmiotowe. Za ekspertów z zakresu określonych zagadnień nie uznaje się dziś po prostu przedstawicieli dyscyplin, pod które te zagadnienia podpadają, lecz raczej badaczy zajmujących się tymi konkretnymi zagadnieniami.

34 Biogram Zbigniewa Mirka wraz z wykazem publikacji zob. http://botany.pl/images/who_pl/ mirek.htm (dostęp: 15.02.2018).

35 Niestety nie udało mi się dotrzeć do pełnego wykazu członków KOP w czasach, w których ukazały się przywołane apele, a jedynie ustalić część nazwisk ówczesnego składu komitetu. Wśród tych nie znalazłem żadnego genetyka, natomiast ekologowie stanowili mniejszość; żadna z tych osób nie prowadziła badań z zakresu zagadnień, o których mowa w apelu.

$36 \mathrm{Tu}$ znów pewne uproszczenie. Na przykład delikatnym tematem jest kwestia tego, na ile biolog wykształcony kilkadziesiąt lat temu jest faktycznie w stanie rzetelnie oceniać wyniki najnowszych badań z obszarów, w których rozwoju nie brał udziału (Z. Mirek ukończył studia na początku lat siedemdziesiątych, natomiast badania nad genetycznie modyfikowanymi roślinami prowadzone są mniej więcej od lat osiemdziesiątych [pierwsza genetycznie modyfikowana roślina została uzyskana w 1983 roku]).

Studia Philosophica Wratislaviensia 13, 2018 z. 3, (C) for this edition by CNS 
PAN w dniu 4 grudnia 2009 r. wysłuchał głosu specjalistów z różnych dziedzin" nie dowiadujemy się jednak, jacy to byli eksperci i jakie dziedziny reprezentowali).

Bardziej dociekliwy i ,krytycznie myślący” Internauta, w którym już pobieżne zapoznanie się z powyższymi apelami powinno wzbudzić wątpliwości co do rzetelności ich autorów, mógłby, szukając oświadczeń eksperckich gremiów na ten sam temat, podobnie jak ja trafić na inne oświadczenie, które ukazało się niedługo po opublikowaniu drugiego z apeli KOP, mianowicie datowane na 3 marca 2010 roku „Oświadczenie Wydziału Nauk Biologicznych PAN w sprawie organizmów genetycznie zmodyfikowanych (GMO)". Jest to dużo bardziej wyważony dokument, którego sygnatariusze nie tyle wskazują konkretne korzyści i zagrożenia związane z GMO, lecz apelują o prowadzenie dyskusji na ten temat w oparciu o przesłanki naukowe, to jest udokumentowane wyniki badań, nie zaś światopoglądowe. Pod oświadczeniem podpisało się z imienia i nazwiska trzydziestu dwóch badaczy różnych specjalizacji ${ }^{37}$.

To oczywiście nie powinien być moment, w którym dociekliwa i „krytycznie myśląca" osoba powinna poprzestać, choć autorytet Wydziału Biologicznego PAN sugeruje dość wysoką wiarygodność treści oświadczenia (wyższą w każdym razie niż autorytet Komitetu). Zatrzymajmy się jednak w tym miejscu i zauważmy kilka rzeczy.

Po pierwsze, ,artykuł”, od którego zacząłem opisane dociekania był, jak już mówiłem, pierwszym wynikiem wyszukiwania hasła „szkodliwość GMO” w wyszukiwarce Google, chociaż odnosił się do dokumentu, który ukazał się prawie dziesięć lat temu ${ }^{38}$. Tymczasem wielu użytkowników traktuje Internet jako źródło najnowszych informacji.

Po drugie, ocena wiarygodności odnalezionej informacji wymagała poświęcenia znacznych nakładów czasu: odnalezienia oryginalnych apeli, zapoznania się z nimi i oceny ich wiarygodności, w tym zapoznania się z zakresem specjalizacji podpisanego eksperta, ustalenia i zapoznania się ze specjalizacjami pozostałych ówczesnych członków komitetu, odnalezienia przeciwważnego oświadczenia innego gremium ekspertów. Jest to wysiłek, na który wielu się nie zdecyduje. Wręcz przeciwnie, jak wskazują niektóre badania, zdecydowana większość użytkowników Internetu, szukając informacji przy pomocy wyszukiwarki Google, zatrzymuje się na pierwszej stronie wyników, z czego duża część na pierwszych kilku wynikach ${ }^{39}$. Do tego, weryfikacja wielu z tych dodatkowych informacji (specjalizacji ekspertów, rzetelności przywoływanych publikacji) wymaga praktycznej wiedzy na temat narzędzi, które to umożliwiają, takich jak bazy danych o naukowcach, indeksy czasopism itp.

37 Z oświadczeniem i listą sygnatariuszy można się zapoznać tu: https://instytucja.pan.pl/index. php/aktwydz2/1373-owiadczenie-wydziau-nauk-biologicznych-pan-w-sprawie-organizmow-genetyczniezmodyfikowanych-gmo?jjj=1508146995160 (dostęp: 15.02.2018).

38 Obecny (początek lutego 2018 roku) pierwszy wynik, jaki otrzymujemy po wprowadzeniu do wyszukiwarki Google tego samego hasła odsyła do artykułu (zresztą o podobnym wydźwięku i wiarygodności) z jesieni 2013 roku.

39 Zob. przyp. 27. 
Po trzecie, wypowiadając się jako przedstawiciel Polskiej Akademii Nauk, uczony dodaje swojej opinii szczególny poziom autoratywności. PAN to wszak, w szczególności dla laika, naukowa instytucja o najwyższym autorytecie w kraju ${ }^{40}$. Nietrudno sobie wyobrazić, w jaki sposób autorytet instytucji stojącej ostatecznie za opisanymi apelami, wykorzystywany być może — czy mógł być, bo mówimy o sprawie sprzed lat — w debatach na temat dopuszczenia do upraw roślin GM w Polsce (już pobieżny przegląd Internetu pod tym kątem ujawnia dyskusje toczone na forach internetowych, w których wskazane apele przywoływane są w charakterze argumentu z opinii eksperta: „Skoro eksperci z PAN ostrzegają przed GMO, to na pewno są one niebezpieczne").

\section{Argumenty z autorytetu w nauce krytycznego myślenia}

Celem powyższych komentarzy i opisanego przykładu było zwrócenie uwagi na potrzebę kładzenia dużego nacisku na wyrabianie kompetencji z zakresu rozpoznawania autorytetów i oceny wiarygodności źródeł w nauczaniu krytycznego myślenia czy praktycznej (racjonalnej) argumentacji. Przyjąłem za oczywiste, że potrzeba odwoływania się do opinii autorytetów pojawia się nieuniknienie wszędzie tam, gdzie uzasadnienie tezy argumentu czy przeprowadzenie wnioskowania wymaga powołania się na obecny stan wiedzy naukowej w określonej dyscyplinie czy dyscyplinach. Przy tym, jak starałem się pokazać, intuicyjna dla wielu strategia polegająca na poszukiwaniu autorytatywnych opinii po prostu wśród przedstawicieli danych dziedzin czy dyscyplin naukowych i wiązanie wiarygodności takich opinii z tytułami naukowymi ich autorów jest w dużej mierze zawodna. Co prawda obserwacje te trudno uznać za odkrywcze, lecz świadomość opisanych tu problemów wydaje się często nie przekładać na nasze praktyki poznawcze i argumentacyjne. Dlatego każdy kurs krytycznego myślenia powinien nie tylko zwracać uwagę na opisane tu problemy, lecz również oferować strategie unikania związanych z nimi zagrożeń. Nawiązując ponownie do opracowanego przez Kisielewicza podręcznika, można się zastanawiać, czy aby nie zatrzymuje się on jedynie na tym pierwszym kroku. Czy inaczej, można zapytać: w jaki sposób prezentowane w Logice i argumentacji praktyczne strategie pozwalają odróżniać poprawne od niepoprawnych argumentów z autorytetu?

$\mathrm{Na}$ zakończenie chciałbym zatem zastanowić się krótko, jakiego rodzaju praktyczne zalecenia dotyczące oceny poprawności argumentów z autorytetu można czy należałoby uwzględniać we współczesnym wykładzie krytycznego myślenia. Jedną z możliwości wydaje mi się wskazanie pytań kontrolnych, jakie można zadawać (sobie lub oponentowi w argumentacji) w przypadku chęci odwołania się do opinii autorytetu lub napotkania takiego odwołania w cudzej argumentacji.

${ }^{40} \mathrm{Na}$ marginesie warto zauważyć, że autor czy autorzy apeli z pełną świadomością wykorzystują autorytet swojej instytucji w celu uwiarygodnienia swoich stwierdzeń; budują swój ethos, pisząc na przykład: „Komitet Ochrony Przyrody PAN, jako interdyscyplinarny zespół badaczy, w którego skład wchodzą zarówno ekolodzy, jak i specjaliści zajmujący się innymi aspektami nauk środowiskowych [...]" (cyt. z pierwszego apelu KOP).

Studia Philosophica Wratislaviensia 13, 2018 z. 3, (C) for this edition by CNS 
Tego rodzaju test pytań kontrolnych zaproponowali Marcin Koszowy i Katarzyna Budzyńska. Jak sugerują, ocena argumentu z autorytetu o schemacie: $i$ jest ekspertem w określonej dziedzinie i twierdzi, że $A$ jest prawdziwe, a zatem $A$ jest prawdziwe, powinna obejmować następujące pytania kontrolne (mające na celu ocenę, czy $A$ faktycznie należy uznać za prawdziwe):

(KP1) Krytyczne pytanie dotyczące wiedzy eksperckiej: Na ile wiarygodny jest $i$ jako ekspert?

(KP2) Krytyczne pytanie dotyczące dziedziny: Czy $i$ jest ekspertem w dziedzinie, do której należy $A$ ?

(KP3) Krytyczne pytanie dotyczące opinii: Co zostało stwierdzone przez $i$, co może być traktowane jak $A$ ?

(KP4) Krytyczne pytanie dotyczące wiarygodności: Czy $i$ jest uczciwy (wiarygodny)?

(KP5) Krytyczne pytanie dotyczące spójności: Czy $A$ nie jest w sprzeczności z innymi ekspertami?

(KP6) Krytyczne pytanie dotyczące uzasadnienia: Czy asercja $i$ posiada uzasadnienie? ${ }^{41}$

Test ten powinien jednak stanowić jedynie punkt wyjścia, ponieważ powyższe pytania są zbyt ogólne ${ }^{42}$. Na przykład pytanie dotyczące dziedziny autorytetu (KP2) należałoby opatrzeć komentarzem dotyczącym, między innymi, specjalizacji we współczesnych naukach. Sięgając raz jeszcze do opisanego wyżej przykładu: mieliśmy w nim do czynienia z profesorem nauk biologicznych, który wygłaszał (między innymi) twierdzenia podpadające bez wątpienia pod zakres tychże nauk. Gdybyśmy na tym poprzestali, można by na KP2 udzielić odpowiedzi twierdzącej. Jak jednak wskazywałem, powinna ona być przecząca - między innymi dlatego, że wygłaszane twierdzenia nie pokrywały się z zakresem specjalizacji domniemanego autorytetu. Z kolei pytanie dotyczące uczciwości (KP4) wymagałoby między innymi omówienia różnego rodzaju konfliktów interesów, w jakich znajdować się mogą naukowcy. Przykładowo badacza rozwijającego określoną teorię naukową można traktować jako rzetelne źródło opinii na temat twierdzeń tej teorii, lecz z ostrożnością należałoby podchodzić do jego opinii na przykład o naukowości tej teorii (w przypadkach, w których ta jest kwestionowana przez innych badaczy). Gdyby więc chcieć uwzględnić powyższy test pytań kontrolnych w nauczaniu rozpoznawania poprawnych i niepoprawnych argumentów z autorytetu, należałoby powyższe pytania obudować bardziej precyzyjnymi zaleceniami (i dodatkowymi pytaniami kontrolnymi). Powinny one obejmować praktyczne sposoby weryfikacji specjalizacji domniemanych autorytetów, oceny wagi ich publikacji, a także oceny rzetelności źródeł, w tym wydawnictw i pism naukowych itp. — co w nauczaniu najlepiej można realizować poprzez praktyczne ćwiczenia na zajęciach, nie należy jednak z tego względu pomijać tych zagadnień w podręcznikowym wykładzie ${ }^{43}$.

${ }^{41}$ M. Koszowy, K. Budzyńska, op. cit., s. 134-135.

42 Można się wręcz zastanawiać, na ile odpowiedź na niektóre z nich w określonych sytuacjach sama w sobie nie wymagałaby wiedzy eksperckiej.

${ }^{43}$ Niektóre stwierdzenia, uwagi czy proponowane zadania, z jakimi można się spotkać w podręczniku sugerują, że na prowadzonych przez siebie kursach autor pogłębia zagadnienia, o których tutaj mowa. Poza tymi odnoszącymi się do kwestii oceny wiarygodności źródeł i argumentu z autorytetu można tu wskazać zaproponowane na s. 192-193 zadanie: „Rozważyć argumenty odnoszące się do osób lub opinii innych (ad hominem, pro hominem, z autorytetu, z powszechnej opinii) i ustalić warunki, przy których te argumenty można uznać za przekonujące, oraz jak można je obalać, wskazując na niespełnienie któregoś z warunków". Takie zadanie stanowi doskonały pretekst do rozwinięcia zagad- 
Innym rodzajem praktycznego zalecania byłaby sugestia, aby mierzyć zamiary na siły. Ocena wiarygodności autorytetu czy źródła wymaga dziś często poświęcenia znacznych nakładów czasu i energii. Jak zwracali uwagę niektórzy moi studenci, z praktycznych względów nie jesteśmy w stanie sprawdzić wiarygodności każdej informacji czy opinii. Wielu zniechęca to do jakichkolwiek dociekań. Aby więc uchronić studentów przed paraliżujaccym nadmiarem sceptycyzmu i krytycy$\mathrm{zmu}^{44}$, można ich zachęcać do poprzedzania dociekań pytaniami dotyczącymi wagi, jaką przypisuje się danej informacji czy opinii eksperckiej: Do jakich celów będę je wykorzystywał? Co ryzykuję, jeśli wezmę fałsz za prawdę? Czyli, innymi słowy, do określania, jak ważne jest dla nich w danym przypadku dotarcie do prawdy i dostosowywania poziomu dociekliwości do wagi zagadnienia (na przykład daleko idąca weryfikacja opinii domniemanego autorytetu, którą pragnie się wykorzystać na potrzeby własnego wnioskowania naukowego vs jedynie upewnienie się co do specjalizacji domniemanego autorytetu, którego opinią podpiera się oponent w koleżeńskiej argumentacji na, z naszego punktu widzenia, mało istotny temat). Z oczywistym zastrzeżeniem, że zaniechanie dociekań powinno sugerować przyjęcie postawy sceptycznej, nie zaś bezkrytyczną akceptację.

Wszystko to mieści się w zakresie wyrabiania w studentach niezbędnej w krytycznym myśleniu postawy rozsądnego metodologicznego sceptycyzmu, w którym to względzie, jak sądzę, opracowany przez A. Kisielewicza podręcznik w dużej mierze spełnia swoje zadanie. To zaś, czego w nim moim zdaniem zabrakło, to właśnie praktyczne zalecenia pozwalające przełożyć tę postawę na praktykę krytycznego myślenia, wnioskowania i argumentacji w określonym tu kontekście argumentów $\mathrm{z}$ autorytetu.

\section{Arguments from authority and critical thinking. Side notes to Logic and Argumentation by Andrzej Kisielewicz}

\section{Summary}

The article focuses on the role of arguments from authority — or, more precisely, arguments from expert opinion - in rational argumentation and reasoning, in the contemporary context of specialisation of the sciences on the one hand, and the abundance of information on the other. The pretext for this is provided by Andrzej Kisielewicz's new book: Logika i argumentacja. Praktyczny kurs krytycznego myślenia (Logic and Argumentation. A Practical Course In Critical Thinking). I point out that, although Kisielewicz's book is a valuable contribution to the Polish market of textbooks on argumentation, practical logic and critical thinking, it understates the importance of teaching the ways of proper assessment of arguments from authority, credibility of experts and information sources. I argue that

nienia oceny poprawności argumentów z autorytetu (i, oczywiście, innych wskazanych), jeśli jednak książka Kisielewicza ma stanowić pozycję również dla szerszego grona — na przykład studentów, którzy w swoich programach nie mają zajęć z krytycznego myślenia — sugestie co do warunków oceny tych argumentów powinny w niej zostać explicite wyrażone. 
arguments from authority should not be by definition dismissed as fallacies; on the contrary, appealing to authority (to expert opinion) is an unavoidable element of rational argumentation - at least whenever the discussion requires one to refer to contemporary scientific knowledge. However, relying on experts' opinions involves genuine risks to the rationality of the debate, many of them having to do with the abundance of pseudoexperts and irresponsibility on the side of some scientists (an extensive example is provided by the presentation of statements on GMO's made by a certain Polish body of scientists). Therefore, the ability to distinguish correct appeals to authority from faulty ones (including the ability to tell actual experts from pseudoexperst and reliable sources of information from unreliable ones) should be considered a crucial competence which critical thinking courses should teach. 